\title{
Immunotherapeutic clearance of systemic amyloid deposits by antibodies to serum amyloid $P$ component
}

\author{
Mark B Pepys \\ Wolfson Drug Discovery Unit, Centre for Amyloidosis and Acute Phase Proteins, Royal Free \\ Campus, University College London, UK
}

Address for correspondence: Professor Sir Mark Pepys, UCL Royal Free Campus, Rowland Hill Street, London NW3 2PF E-mail: m.pepys@ucl.ac.uk

The extracellular amyloid deposits which disrupt tissue architecture are unequivocally pathogenic and a major cause of organ dysfunction in all forms of systemic amyloidosis [1]. Systemic amyloid deposits generally evoke little or no local or systemic inflammatory response. In contrast to the usual rapid spontaneous removal of extracellular debris, amyloid deposits regress slowly if at all, even when the abundance of amyloid fibril precursor proteins is reduced [1]. Swift therapeutic reduction of amyloid load is therefore highly desirable. Antibodies to serum amyloid $\mathrm{P}$ component (SAP) achieve this objective by targeting the SAP which is universally present in all human amyloid deposits. It is obviously impossible to administer anti-SAP antibodies alone because the circulating SAP in the plasma would form pathogenic immune complexes and also consume the antibody before it could reach SAP in the amyloid deposits. However the drug CPHPC (hexanoyl bis(D-proline), safely and potently depletes circulating SAP [2] but leaves some SAP in the amyloid deposits [3] to serve as the antigen target for the therapeutic antibody. Prior administration of CPHPC thus makes it feasible to administer anti-SAP antibody which can bind to the SAP coated amyloid. In
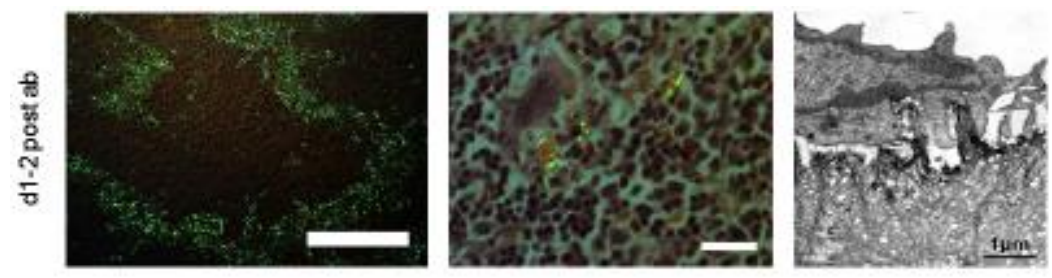

Extensive extracellular amyloid; Formation of MGCs \pm amyloid engulfment
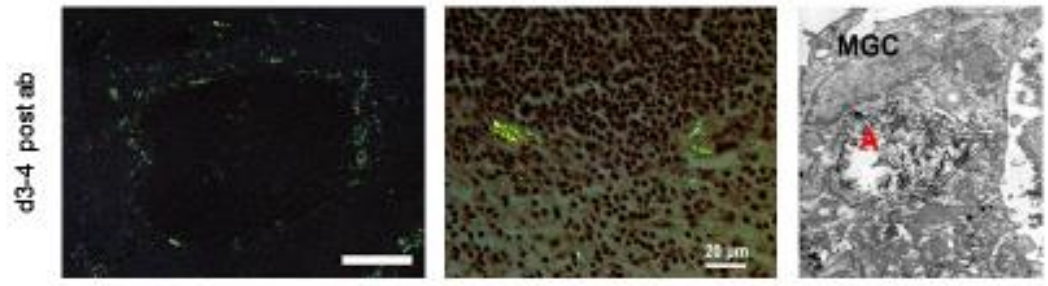

Substantially reduced amyloid $\rightarrow$ Mostly intracellular $\rightarrow$ MGC phagosomes with degraded deposits murine experimental models, amyloid clearance by anti-SAP depends on classical complement pathway activation and macrophages [4]. It is mediated by antibody binding to amyloidassociated SAP, leading to complement activation, C3 deposition on the amyloid, attraction and then engagement of macrophages that rapidly fuse to form multinucleated giant cells [4]. These cells have a unique phenotype, which we have recently characterised [5], and which specifically equips them to surround, engulf and destroy large complement opsonised objects.

The obligate therapeutic partnership of CPHPC and anti-SAP antibody is being developed by GlaxoSmithKline and has been safe and generally well tolerated in patients with systemic AL, AA, AApoAI and AFib amyloidosis [6, 7]. Anti-SAP infusion triggered immediately increased production of IL-6, but not TNFa. Early acute-phase responses of CRP and SAA were followed by substantial plasma $\mathrm{C} 3$ depletion $[6,7]$. Variable infusion reaction were abrogated by hydrocortisone and antihistamine premedication but most subjects receiving higher antibody doses developed skin rashes, though only one was serious and it responded to oral prednisone [6,7]. Importantly, no increased dysfunction was observed in any amyloidotic or other organs, including the kidney [6, 7]. Amyloid clearance was unequivocally confirmed by reduction of extracellular volume in amyloidotic organs, reduction of amyloid load measured by SAP scintigraphy and decreased liver stiffness in patients with hepatic amyloidosis $[6,7]$. Crucially, reduction of amyloid load was 
associated with improved organ function, especially in the liver [6, 7]. Repeat antibody doses progressively reduced amyloid load with corresponding functional improvement $[6,7]$.

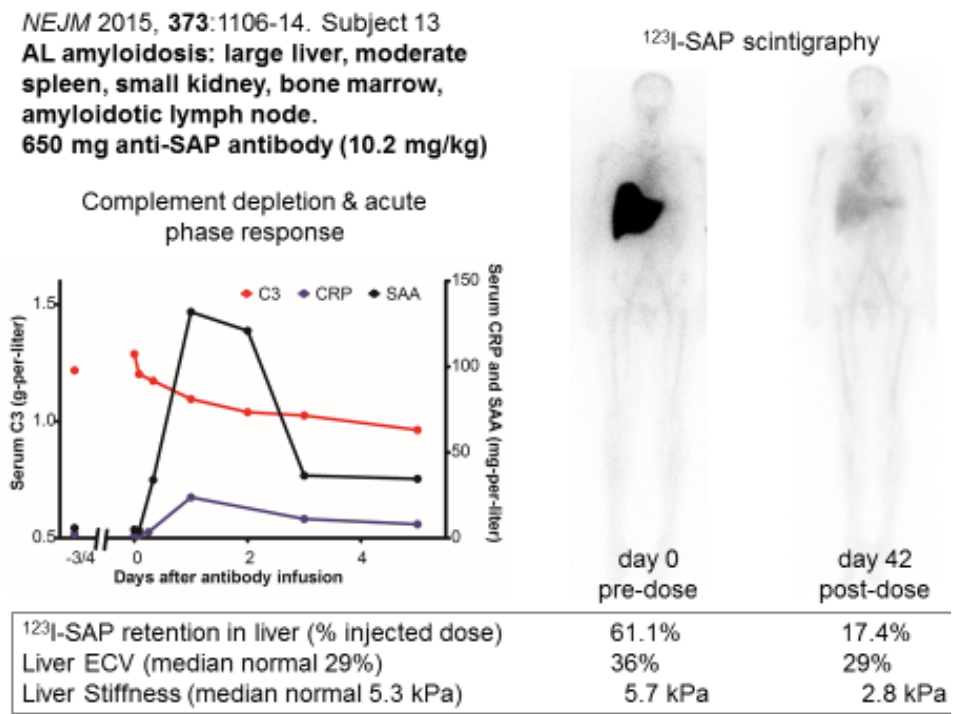

Effect of single CPHPC + anti-SAP antibody dose

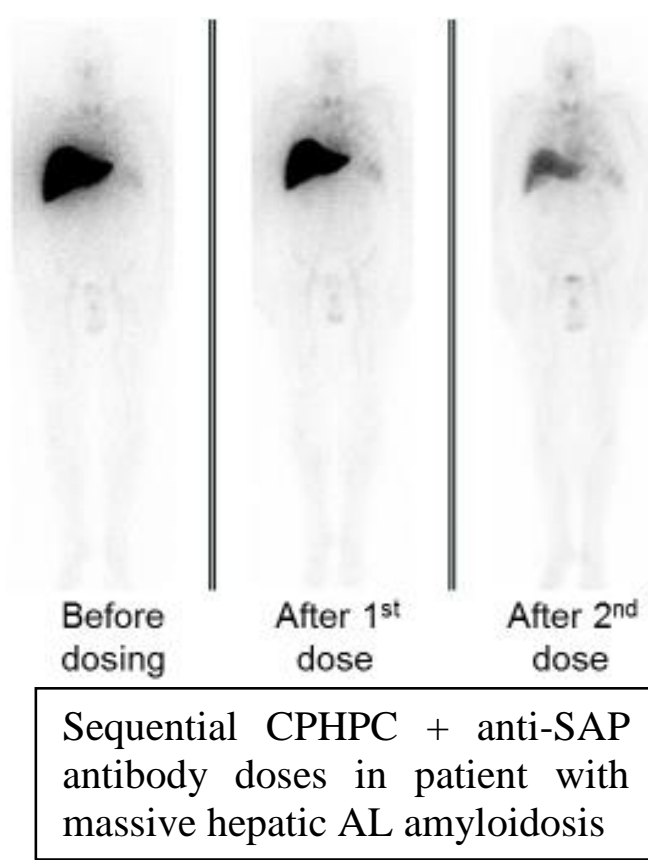

Conclusion. Anti-SAP antibody triggers rapid non-tissue damaging amyloid clearance from the extracellular space, a process which is otherwise very slow or absent. Cardiac involvement is the major cause of morbidity and mortality in systemic amyloidosis and a phase 2 trial of repeat CPHPC plus anti-SAP dosing in patients with cardiac AL and ATTR amyloidosis is now planned.

Declaration of interest. MB Pepys is the inventor on patents for CPHPC and CPHPC plus anti-SAP antibody. He founded and owns shares in Pentraxin Therapeutics Ltd, the UCL spinout company that owns these patents and has licensed them to GSK for development.

References. 1. Pepys MB. Amyloidosis. Annu. Rev. Med. 2006;57:223-41

2. Pepys MB, Herbert J, Hutchinson WL, Tennent GA, Lachmann HJ, Gallimore JR, Lovat LB, Bartfai T, Alanine A, Hertel C, Hoffmann T, Jakob-Roetne R, Norcross RD, Kemp JA, Yamamura K, Suzuki M, Taylor GW, Murray S, Thompson D, Purvis A, Kolstoe S, Wood SP, Hawkins PN. Targeted pharmacological depletion of serum amyloid $\mathrm{P}$ component for treatment of human amyloidosis. Nature 2002;417:254-9

3. Gillmore JD, Tennent GA, Hutchinson WL, Gallimore JR, Lachmann HJ, Goodman HJB, Offer M, Millar DJ, Petrie A, Hawkins PN, Pepys MB. Sustained pharmacological depletion of serum amyloid P component in patients with systemic amyloidosis. Br. J. Haematol. 2010;148:760-7

4. Bodin K, Ellmerich S, Kahan MC, Tennent GA, Loesch A, Gilbertson JA, Hutchinson WL, Mangione PP, Gallimore JR, Millar DJ, Minogue S, Dhillon AP, Taylor GW, Bradwell AR, Petrie A, Gillmore JD, Bellotti V, Botto M, Hawkins PN, Pepys MB. Antibodies to human serum amyloid P component eliminate visceral amyloid deposits. Nature 2010;468:93-7

5. Milde R, Ritter J, Tennent GA, Loesch A, Martinez FO, Gordon S, Pepys MB, Verschoor A, Helming L. Multinucleated giant cells are specialized for complement-mediated phagocytosis and large target destruction. Cell Rep. 2015;13:1937-48

6. Richards DB, Cookson LM, Berges AC, Barton SV, Lane T, Ritter JM, Fontana M, Moon JC, Pinzani M, Gillmore JD, Hawkins PN, Pepys MB. Therapeutic clearance of amyloid by antibodies to serum amyloid P component. N. Engl. J. Med. 2015;373:1106-14

7. Pepys MB, Cookson LM, Barton SV, Berges AC, Lane T, Hutt D, Fontana M, Moon JC, Gillmore JD, Wechalekar W, Hawkins PN, Richards DB. Dose-dependent progressive immunotherapeutic clearance of systemic amyloid deposits by repeated doses of antibody to serum amyloid P component (SAP). Blood 2015;126:1836 